http://journals.ums.ac.id/index.php/ijolae

\title{
Students' Spatial Reasoning in Solving Geometrical Transformation Problems
}

\author{
Serli Evidiasari1 ${ }^{1}$, Subanji ${ }^{2}$, Santi Irawati ${ }^{3}$ \\ 1,2,3 Faculty of Mathematics and Natural Science, Universitas Negeri Malang, Indonesia
}

DOI: 10.23917/ijolae.v1i2.8703

Received: August 23 $3^{\text {rd }}, 2019$. Revised: August 25 ${ }^{\text {th }}, 2019$. Accepted: August 29 ${ }^{\text {th }}, 2019$ Available Online: August $29^{\text {th }}, 2019$. Published Regulary: August $29^{\text {th }}, 2019$

\begin{abstract}
This study describes spatial reasoning of senior high school students in solving geometrical transformation problems. Spatial reasoning consists of three aspects: spatial visualization, mental rotation, and spatial orientation. The approach that is used in this study is descriptive qualitative. Data resource is the test result of reflection, translation, and rotation problems then continued by interview. Collecting data process involves 35 students. They are grouped to three spatial reasoning aspects then selected one respondent to be the most dominant of each aspect. The results of this study are: (1) the students with spatial visualization aspect used drawing strategy and non-spatial strategy in solving geometrical transformation problems. She transformed every vertex of the object and drew assistance lines which connect every vertex of the object to center point; (2) the students with mental rotation aspect used holistic and analytic strategies in solving geometrical transformation problems. Using holistic strategy means imagining the whole of transformational objects to solve easy problems. While using analytic strategy means transforming some components of objects to solve hard problems; (3) the students with spatial orientation didn't involve mental imagery and she only could determine the position and orientation of the object in solving geometrical transformation problems.
\end{abstract}

Keywords: spatial, reasoning, geometry

Corresponding Author:

Serli Evidiasari, Mathematics and Natural Science Faculty of Universitas Negeri Malang

Email: evidisari.1703118@students.um.ac.id

\section{Introduction}

Problem solving skill has to be sharpen and be built. Mukhopadhyay (2013) states that problem solving skill is one of technical, scientific, and complex quality parameter in modern society. It was influenced by the growth of knowledge and technology because problems faced by society are more complex. More than that, most of jobs will involve problem solving process. It is line with Saygilı (2017), that problem solving can be found in any aspect of life. Wai, et al. (2009) explains that spatial ability affects success in science and technology. Chao $\mathrm{Yu}$, et al. (2015) states that problem solving is a approach of how scientists think when making technology product. Cai \& Lester (2010) explains that problem solving gives an intelectual challenge to increase students' mathematical understanding.

Developing problem solving skill is one of the main aims in mathematics learning. Mulyono \& Hardiyanti (2018) states that one of primary education intention is preparing students to solve any problem they faced everyday. Yusnia (2018) says that in curicullum of mathematics, problem solving is an 
important part. As an effort to support achieving the aim, the government puts problem solving as one of the mathematics learning standard process. According to NCTM (2000), by learning how to solve mathematics problems, students will understand how to think, to develop their high curiosity, and to have a confidency in facing the unfamiliar situation.

The role of teacher as learning facilitator is very important. Stacey (2006) states that teachers have to design satisfying, meaningful, and effective problem solving learning. Chapman (2015) explains that teachers have to help students to be good in problem solving. According to Cai \& Lester (2010), teacher also takes a role in revising, choosing, and developing a task which improve students to understand and to master in solving problems.

The problems designed by teachers can be routine problems and non-routine problems. A routine problem is a problem which students can find or recognize the solving strategy easily because they often find it in textbook or other sources (Pehkonen, et al, 2013; Özreçberoğlu \& Çağanağa, 2018). While non routine problem is a problem which needs the particular technique and deep thinking to find the solving strategy because it is unfamiliar for students (Pehkonen, et al, 2013; Kolovou, et al, 2009). Yazgan (2016) states that non routine problem is a problem that there is no explicit solving approach such that it is difficult to predict.

Giving non routine problem is important because problems faced by students in daily life have complex and complicated structure. It is line with Wright (2001), that to enhance students' skill in problem solving, students need to learn problems related to real context. Daguplo (2013) states that non-routine problem solving also develops mathematical reasoning.

According to Hardman \& Macchi (2004), based on the strategy, one type of reasoning is spatial reasoning. Subroto (2012) states that spatial reasoning is an activity to percept, store, make, and communicate objects in three dimensional spaces to make conclusion from given information. In National Research Council (2006), it is explained that spatial thinking consists of various cognitive skills, they are: perceptual and declarative knowledge or cognitive operation, that is used to transform or to group the shape, etc.

It is important to build and to develop spatial reasoning because it can help and support student to understand a geometry concept (NCTM, 2000). Septia, et al. (2018) explains that spatial reasoning is a part of mental ability in mathematical thinking process. Hartatiana (2018) states that spatial reasoning in geometry can help students to find mathematics problem solution. According to Ontario (2014), it is also important for students to have mathematical thinking and achievement that can be built through experience and education. Subroto (2012) suggests that spatial ability need to be developed to mathematics learning in the school by including it into three dimensional space topics.

According to Lowrie, et al. (2016), in general, there are terms related to spatial reasoning, they are: spatial visualization, mental rotation, and spatial orientation. Spatial visualization is one's ability to either transform or to manipulate spatial pattern into other visual shapes (Lowrie, et al., 2016, 2018). Shepard \& Metzler (1971) defines mental rotation is the ability in imagining rotated objects in the same orientation or direction. While Ramful, et al. (2016) explains that to identify mental rotation, stu- 
dents are given an object then they rotate it. Sholl, et al. (2000) says that spatial orientation is the ability associated to navigation or orientation in unfamiliar environment. Based on Ramful, et al. (2016), in spatial orientation task, students are asked to determine the position of object by self positioning mentally or physically.

Ontario (2014) states that a student who has a high spatial reasoning will perform the better ability in mathematics. Garderen, et al. (2006) states that the usage of visual images correlate positively in solving mathematical problems. In line with Boonen, et al. (2016), students who use visual representation, in solving problems is more accurate than who does not. Cheng \& Mix (2014) says that spatial reasoning can recondition the learning result. Therefore, in mathematics, spatial reasoning is really needed.

In mathematics, geometry is considered as difficult topic. From previous researches, Retnawati, et al. (2017) explains that students had some misconceptions and less knowledge toward the concepts about geometrical problems, difficulties to understand the information given in the test item, and in applying the geometrical concepts. Özerem (2012) gets the result that seventh grade students had some misconceptions and less knowledge related geometry subject.

One of the geometry topic studied in senior high school is geometrical transformation. Based on interview with teachers of SMA Negeri 1 Lawang related to geometrical transformation learning method, the researchers got the information that the way the students to determine the image of points or line were by using matrices. They memorized those matrices such that whenever they forget, they have a difficulty to solve the problems. According to Ananggih, et al. (2017), memorizing method can make meaningless and ineffective learning. Bansilal \&
Naidooo (2012) recommends students to be involved in geometrical transformation activity that emphasize on conversion. Arcavi (2003), states that to make students understand the geometry concept, they can use visual representation.

\section{Method}

This study involved 35 second grade students of SMA Negeri 1 Lawang. The researchers gave geometrical transformation problems and selected some to be respondents based on their works. Selected respondents consist of 3 students who fulfill criteria, they were: 1 student who had dominancy on spatial visualization aspect, 1 student who had dominancy on mental rotation aspect, 1 student who had dominancy on spatial orientation aspect. A student was said to be with spatial visualization aspect when she/he showed its indicators more than 3 items problem. A student was said to be with mental rotation aspect, when she/he showed its indicators more than 3 items problem. While a student was said to be with spatial orientation aspect when she/he showed its indicators more than 3 items problem. Beside of that, respondents must have good communication ability. Therefore, the researchers asked a suggestion to teachers about student's communication ability to make it easy in collecting data through interview. After that, respondents were interviewed aimed to confirm and to dig their works deeply.

The design of this study was descriptive qualitative. To see students's reasoning, the data was collected using interview method and student's work about geometrical transformation problems. Instruments used in this study were six problems; 2 reflection problems, 2 translation problems, and 2 rotation problems and interview guide. The type of problem given to student was about 
generalizing form $\left(\mathrm{x}^{\prime}, \mathrm{y}^{\prime}\right)$ after drawing an object either before or after being transformed. Given problems were non routine for student because they never learn how to draw the image of geometrical transformation. Problems given to student is shown in Appendix.
The work of 35 students were analyzed based on indicators of spatial reasoning aspects in Table 1. After that, they were grouped in 3 aspects and one student who had dominancy to each aspect would be selected as follows: (1) spatial visualization aspect, (2) mental rotation aspect, and (3) spatial orientation aspect.

Table 1. Spatial Reasoning Aspects Indicators

\begin{tabular}{llll}
\hline \multicolumn{1}{c}{ Spatial Visualization } & \multicolumn{1}{c}{ Mental Rotation } & \multicolumn{1}{c}{ Spatial Orientation } \\
\hline \multirow{3}{*}{ Indicators } & $\begin{array}{l}\text { The student understands the } \\
\text { transformation principles, it de- } \\
\text { notes by she/he who is able to } \\
\text { transform or manipulate the ob- }\end{array}$ & $\begin{array}{l}\text { The student is able to rotate } \\
\text { the object vertically, hori- } \\
\text { zentally, or } \boldsymbol{\theta}^{\circ} \text { as a whole }\end{array}$ & $\begin{array}{l}\text { The student } \\
\text { understands the effect } \\
\text { of orientation of given } \\
\text { transformation. It } \\
\text { jenotes by she/he who } \\
\text { transformed correctly }\end{array}$ \\
& $\begin{array}{l}\text { object correctly without } \\
\text { drawing or as a component } \\
\text { of the object. }\end{array}$ & $\begin{array}{l}\text { can determine the } \\
\text { position of the object } \\
\text { correctly. }\end{array}$ \\
\end{tabular}

Combined from Lowrie dkk (2016), Shepard dan Metzler (1971), Sholl dkk (2000)

All of three respondents were analyzed qualitatively. The researchers described how respondents drew the image of transformation to generalize general forms of coordinate point $\left(\mathrm{x}^{\prime}, \mathrm{y}^{\prime}\right)$ from tests and interviews.

\section{Result and Discussion}

Student with spatial visualization aspect is labeled by $S_{1}$. Student with mental rotation aspect is labeled by $\mathrm{S}_{2}$. While student with spatial orientation aspect is labeled by $S_{3}$.

\section{Spatial Visualization}

Based on the work, $S_{1}$ can transform or manipulate objects by drawing either before or after transforming it correctly although there are some errors. After it is confirmed through interview, it was caused by inaccuracy. For the first reflection problem, that was when students were asked to draw image after reflection to $\mathrm{x}$ axis, $\mathrm{S}_{1}$ could do it well, as it was shown in Figure 1.

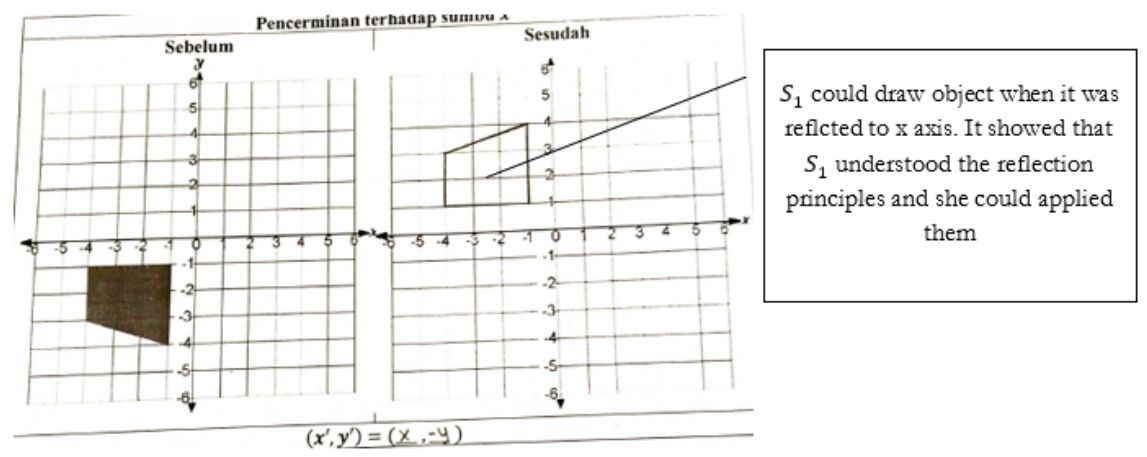

Figure 1. $S_{1}$ work for Problem I about Reflection (respect to the $\mathrm{x}$-axis)

During interview, $\mathrm{S}_{1}$ could understand that in drawing the reflection image respect to $\mathrm{x}$-axis, her strategy was reflecting every vertex of object to center point. $\mathrm{S}_{1}$ was also able to generalize general form ( $\left.x^{\prime}, y^{\prime}\right)$ as it was shown in interview passage below. 
$\mathrm{P} \quad$ : How did you get the reflected image? Please explain to me.

$\mathrm{S}_{1}$ : I thought that the distance between a point and the mirror was equal to the distance between image respected to the mirror. So I took one point and reflected it. Then I did for all of the vertices in the same way. (spatial visualization)

$\mathrm{P}$ : How did you get the general form of ( $\left.\mathrm{x}^{\prime}, \mathrm{y}^{\prime}\right)$ ?

$\mathrm{S}_{1}$ : By looking at the coordinate. Since the sign of number respected to the $\mathrm{y}$ axiswas contrary withthe origin number of the $y$ and nothing change with the num- ber respected to $\mathrm{x}$-axis. For example I took one point $(-1,-1)$, it became $(-1,1)$.

$\mathrm{P} \quad$ : How about the other points?

$\mathrm{S}_{1}$ : I did the same as the others, Miss. Surely it's same for all vertices.

For the problem II about reflection, $\mathrm{S}_{1}$ was able to draw the object before it was reflected which respect to the $\mathrm{y}=\mathrm{x}$ line, as shown in Figure 2.

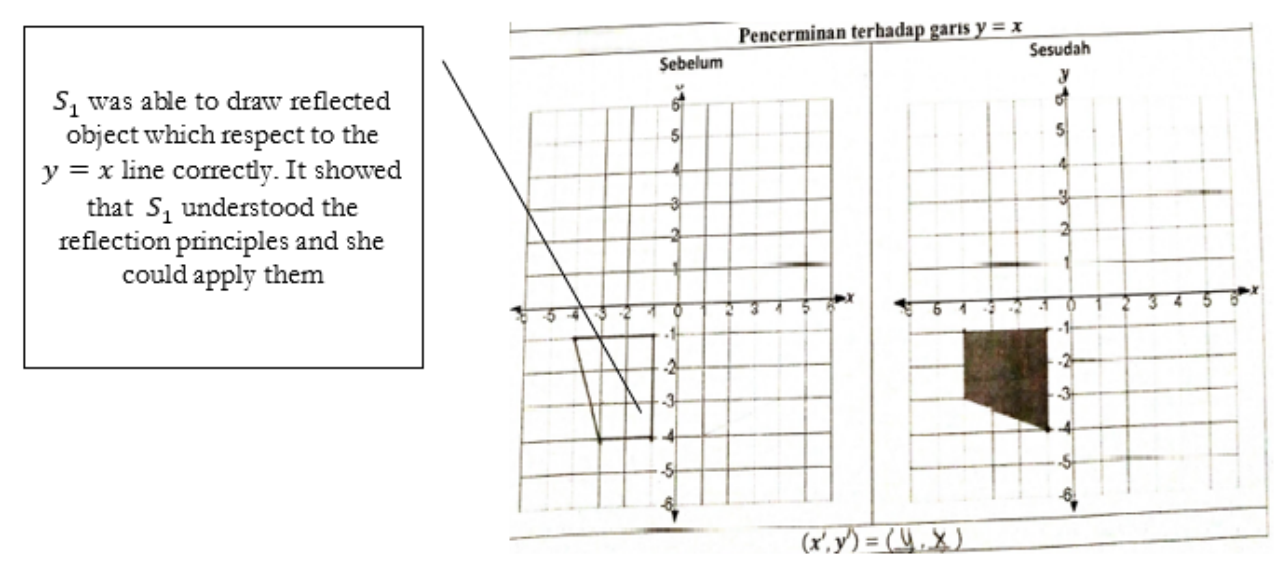

Figure 2. $\mathrm{S}_{1}$ ' work for Problem II about Reflection (respect to the $y=x$ line)

But in drawing object, $\mathrm{S}_{1}$ only notice the $y=x$ line which affect to coordinate point such that the $\mathrm{y}$ to be the $\mathrm{x}$ and vice versa, as shown in the interview passage below.

$P$ : Did you get any difficulties when drawing object before reflecting it which respect to the line $\mathrm{y}=\mathrm{x}$ ?

$\mathrm{S}_{1}$ : Little bit. At the first time I thought that the mirror was y axis. But I read twice, and I realize that I made errors in reading the instruction, it should be the line $\mathrm{y}=\mathrm{x}$.

$\mathrm{P}$ : Could you draw the line $\mathrm{y}=\mathrm{x}$ ?
$\mathrm{S}_{1} \quad$ : No. I could not, Miss. .

$\mathrm{P}$ : So how did you draw this object before it was reflected?

$\mathrm{S}_{1}$ : Since the mirror is the line $\mathrm{y}=\mathrm{x}$, so it must be reversed, the number respect to $\mathrm{x}$-axis should be respect to y axis. After that, I drew them (spatial visualization)

For the first problem about translation, $\mathrm{S}_{1}$ could draw the translated object, as shown in Figure 3 below. 


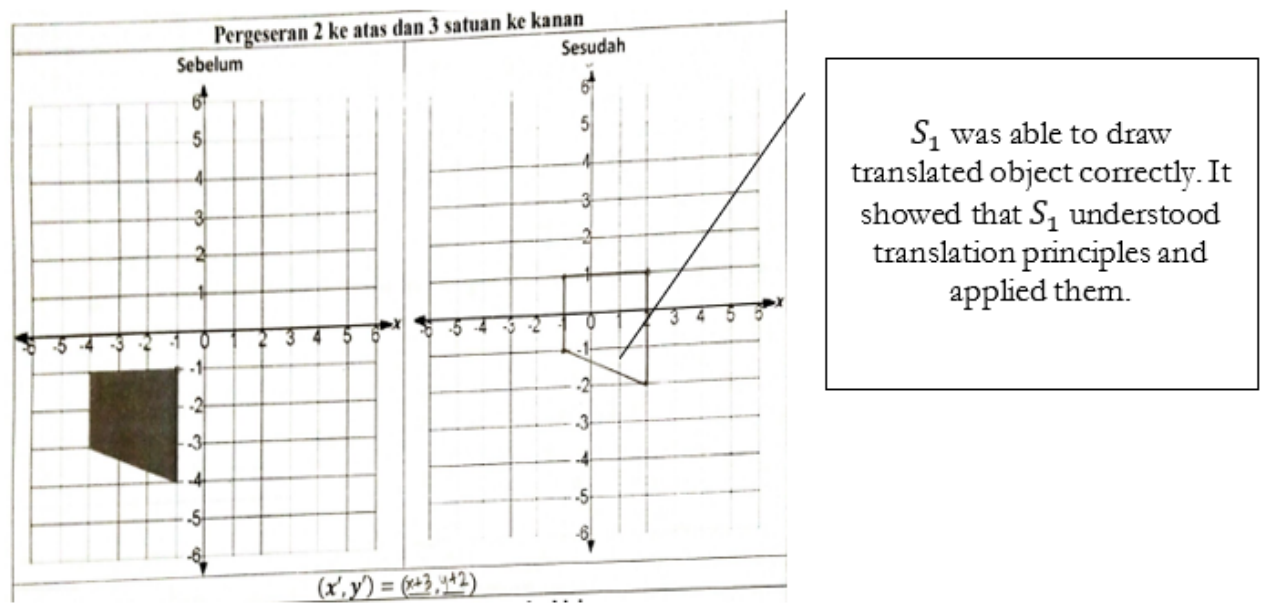

Figure 3. $S_{1}$ 's work for Problem I about Translation ( 2 units to the up and 3 units to the right)

For the second problem about translation, $\mathrm{S}_{1}$ made a mistake because she shifted the image of the object.
The researchers assumed that she shifted the object after translating it as shown in the following Figure 4.
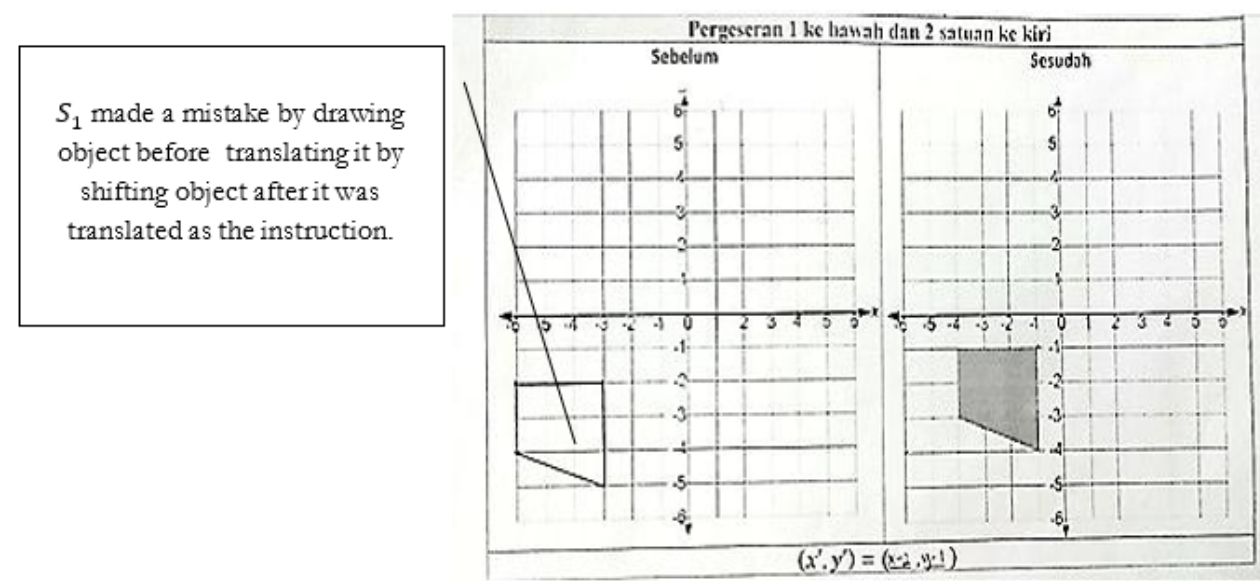

Figure 4. $S_{1}$ 's work for Problem II about Translation ( 1 unit to the down and 2 units to the left)

During interview, she realized that she made mistakes and fixed them to get the correct answer. So it could be caused by inaccuracy, as shown in the following interview passage.

P : Did you get this object after shifting the object? Now try to check it.

$\mathrm{S}_{1}$ : Yes, Miss. I made a mistake. Because I shifted the image of the object.

$\mathrm{P} \quad$ : So, how should it be?

$\mathrm{S}_{1}$ : It should be reversed. In the instruction, the object is shifted to the down and the left. To draw the object before translating it, I need to shift in the opposite direction, 1 unit to the up and 2 units to the right (spatial visualization).

For rotation problems, $\mathrm{S}_{1}$ could manipulate the object before or after it was translated. She made assistance lines that connect all vertices of object and connected to the center point then formed angles as the instruction. $\mathrm{S}_{1}$ had to draw such that she can imagine the rotation image. So, assistance lines can help her to solve the rotation problems, as shown in Figure 5 below. 


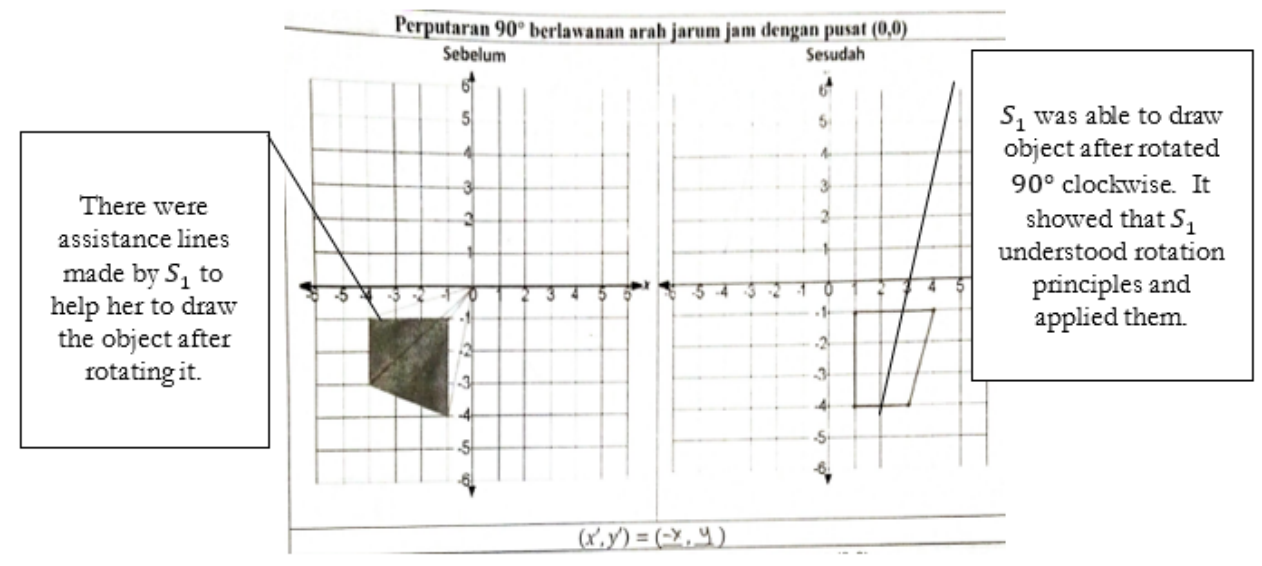

Figure 5. $\mathrm{S}_{1}$ 's work for Problem I about Rotation ( $90^{\circ}$ clockwise)

There was an error in generalizing $\left(x^{\prime}, y^{\prime}\right)$ form, but $S_{1}$ realized it was because she applied one point only where the $\mathrm{x}$ and the $y$ were same number, as shown I on the following interview passage.

$\mathrm{P} \quad$ : When did you read the problem about rotation, what did you do first? Imagining the position of the image then drawing or vice versa?

$\mathrm{S}_{1}$ : Drawing first then I could imagine it.

$\mathrm{P}$ : Tell me how you draw the object before and after it was rotated.

$\mathrm{S}_{1}$ : All vertices were connected to center point $(0,0)$ then I draw $90^{\circ}$ angles (spatial visualization)
$\mathrm{P}$ : The (x',y') form for $90^{\circ}$ counterclockwise is $(-\mathrm{x}, \mathrm{y})$. now try to check if your answer was correct.

$\mathrm{S}_{1}$ : I made a mistake, Miss. yesterday I checked one point only, that was $(-1,-1)$. Then the general form should be $(-y, x)$.

\section{Mental Rotation}

From $\mathrm{S}_{2}$ 's work entirely, he could solve all of the problems correctly. He had three spatial reasoning aspects, but he had a dominancy in a mental rotation aspect. For problem I about reflection, $S_{2}$ did not get any difficulties in drawing the image of reflection to $\mathrm{x}$-axis. $\mathrm{S}_{2}$ 's work is shown in Figure 6.

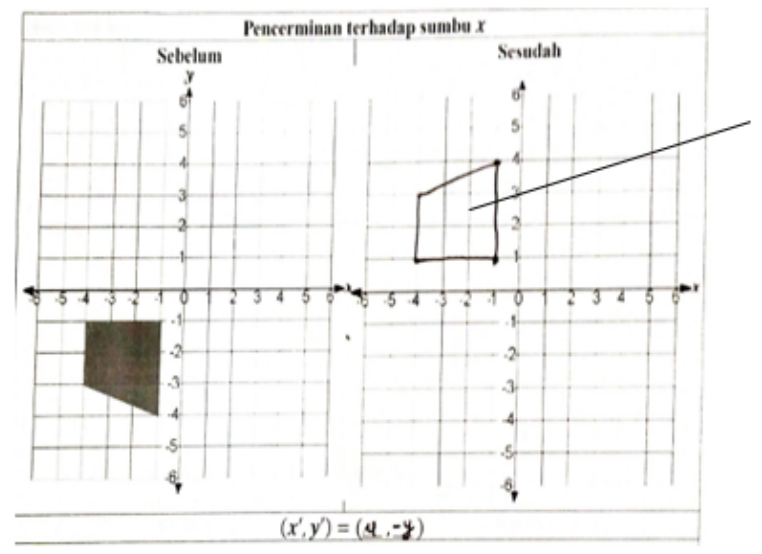

$S_{2}$ was able to draw the image of relflection to $\mathrm{x}$-axis. It showed that $S_{1}$ understood the reflection princples and applied them

Figure 6. $\mathrm{S}_{2}$ 's work about Problem I (Reflection to the $\mathrm{x}$-axis)

It can be concluded that $\mathrm{S}_{2}$ imagined the in solving the reflection problem, as shown object by flipping vertically or horizontally on the passage of interview below. 
$\mathrm{P}$ : How did you get the reflected object? Please, explain to me.

$\mathrm{S}_{2}$ : If the object was reflected to $\mathrm{x}$-axis, then it was flipped.

$\mathrm{P}$ : What do you mean by flipping?

$\mathrm{S}_{2}$ : How to say it.... (he gave illustration by his gesture hands). Because the mirror was X-axis, I thought directly that the position of this point was here. And the others point followed the reflection principles. (mental rotation)

$\mathrm{P}$ : How did the principle of reflection work?

$\mathrm{S}_{2} \quad$ : It was about flipping

In solving problem II about reflection, when $\mathrm{S}_{2}$ was asked to draw the object before it was reflected to the $y=x$ line, he made the assistance illustration as show in Figure 7.
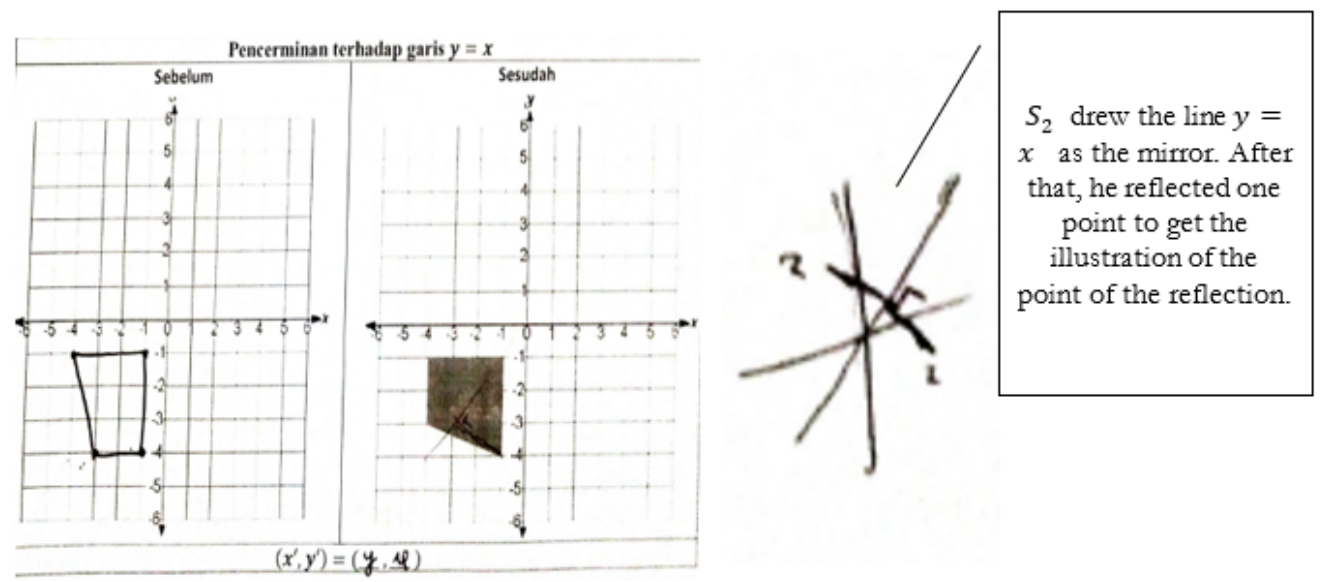

Figure 7. $\mathrm{S}_{2}$ 's work and his assistance drawing for Problem II about Reflection

From the interview, $\mathrm{S}_{2}$ made an assistance drawing by testing one point only. From the assistance drawing, it showed that he was very familiar with the concept of reflection. Then he used it to generalize the other points, as shown on the following interview passages.

P : Didn't you confuse on drawing the object before it was reflected to the line $y$ $=\mathrm{x}$ ? Tell me how you got the reflection image before it was mirrored.

$\mathrm{S}_{2}$ : No Miss. I drew the ilustration. I tried a point that was mirrored against the line $y=x$. Then the $x$ could be the $y$ and the distance was definitely perpendicular. It also held for the y.(mental rotation)

P : How about the others point? Did you try a point only, did not you?

$\mathrm{S}_{2}$ : Since I had known the pattern, so it held for the other points (mental rotation)
For translation problem, $\mathrm{S}_{2}$ made one point, then used it to generalize ( $\left.\mathrm{x}^{\prime}, \mathrm{y}^{\prime}\right)$ form. He understood that the concept of translation did not involve changing the shape, as shown in the following interview passage.

$\mathrm{P}$ : How did you draw the object both before and after they were translated? Please explain to me.

$\mathrm{S}_{2}$ : Translating means shifting. So as the instruction, the object was shifted to 2 units to the right and 3 units to the up. It means that the $\mathrm{x}$ was added by 3 and the $\mathrm{y}$ was added by 2 . I took a point, for example $(-1,-1)$. Then its position was in $(2,1)$. And the object was trapezoid. So the distance between others point and $(2,1)$ were fixed as before it was translated. So I determined the opposite direction, that were 1 unit to up and 2 to the right.

$\mathrm{P}$ : Explain to me. How did you get $\left(\mathrm{x}^{\prime}, \mathrm{y}^{\prime}\right)$ $=(x+3, y+2)$. Why is it not $(x+2, y+3)$ ? 
$\mathrm{S}_{2}$ : Points were shifted to up and to the down affecting to y-axis. While shifting to the right and to the left affected to the $\mathrm{x}$.

For rotation problems, $\mathrm{S}_{2}$ was able to imagine the object either before or after it was rotated without drawing it. One of the methods that help her to imagine was by looking points which close to $\mathrm{y}$-axis and $\mathrm{x}$ axis, as in the following interview passage.

$\mathrm{P}$ : When reading about the rotation problem, what did you do first; imagining where the position of the object after transformated then sketching or drawing first to imagine the object after the picture?

$\mathrm{S}_{2}$ :I have imagined it before I drew it. (mental rotation)

$\mathrm{P}$ : Please explain to me how you get the object either before or after it was rotated.
$\mathrm{S}_{2}$ : I imagined it, Miss. When the object was rotated counterclockwise, I took a point and guessed where its position after being rotated. If the object was lied in quadrant 3 , so the image of the object was in quadrant IV. $(-4,-1)$ was closed to $\mathrm{x}$ axis so the point on the image was closed to y axis. So were the other poinst (mental rotation)

$\mathrm{P} \quad$ : Did you notice the center of rotation?

$\mathrm{S}_{2}$ : Yes, Miss.

\section{Spatial Orientation}

From her entire work, $\mathrm{S}_{3}$ did not solve problem correctly. She drew the position of image although the coordinate points were incorrect. This was because of her spatial orientation aspect more dominant than the others, as shown Figure 8 and Figure 9.

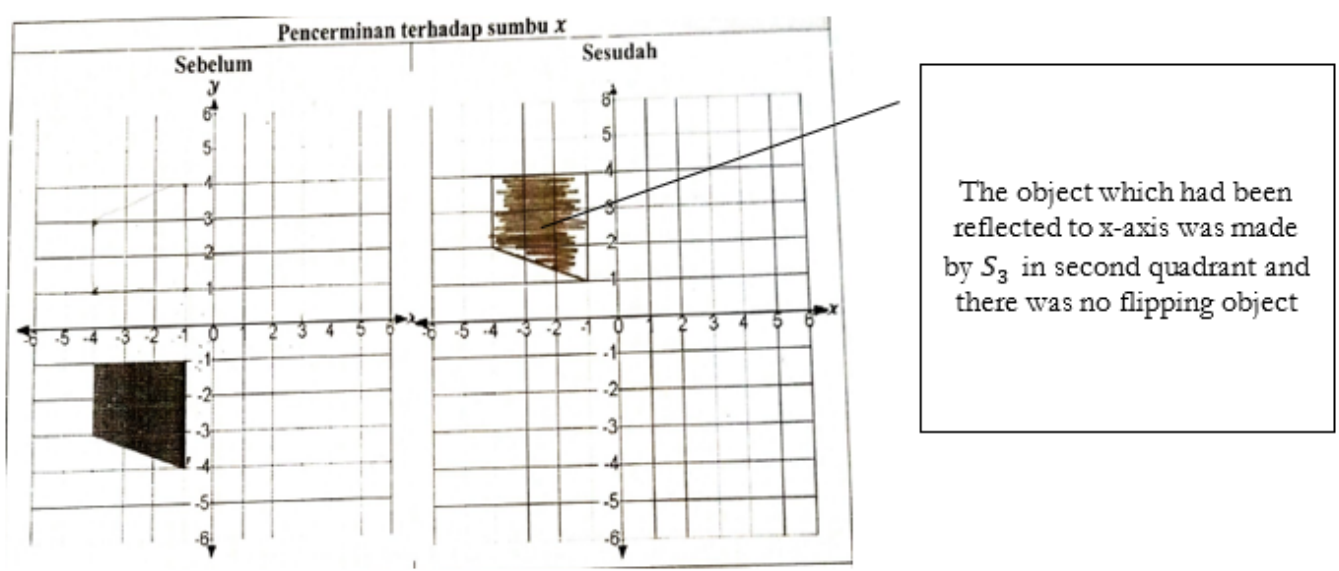

Figure 8. $\mathrm{S}_{3}{ }^{6} \mathbf{s}$ work for Problem I about Reflection (respect to the $\mathrm{x}$-axis) 


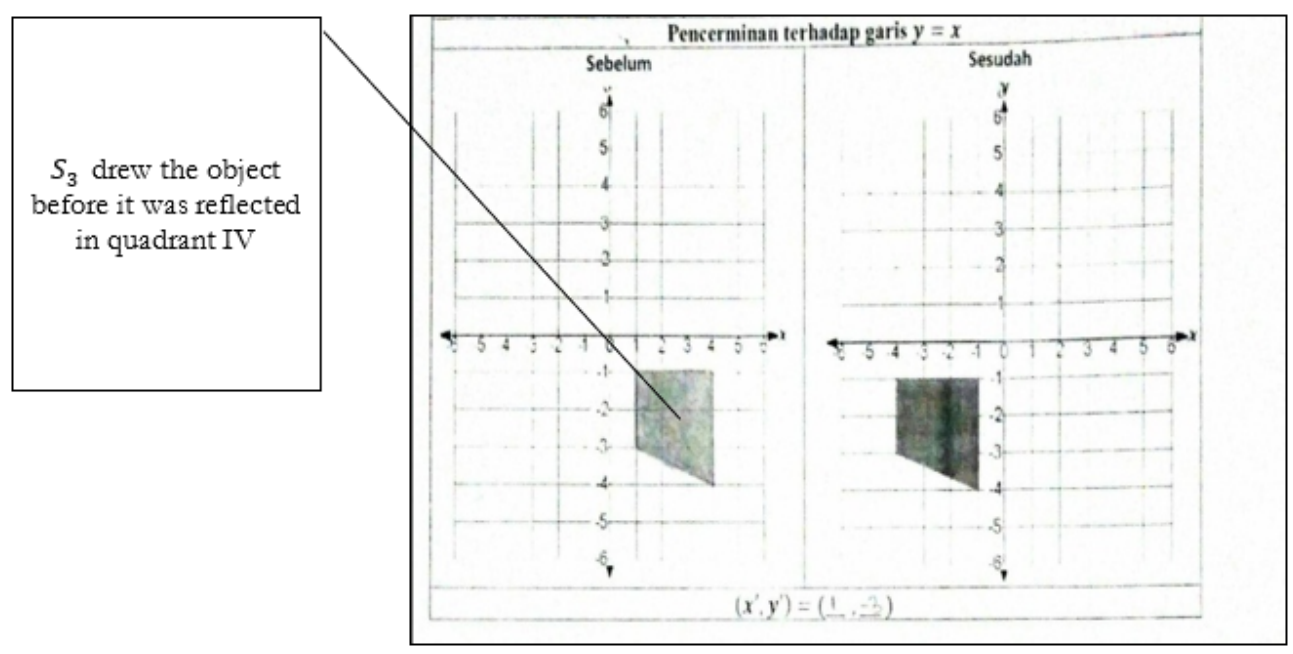

Figure 9. $\mathrm{S}_{3}$ 's work for Problem II about Reflection (respect to the $\mathbf{y}=\mathbf{x}$ line)

From Figure 8, the student could understand that the mirror was $\mathrm{x}$-axis. So the image was in the second quadrant. But $\mathrm{S}_{3}$ did not understand the concept of reflection such that the image was not flipped. From Figure 9 , for the second problem of reflection, $\mathrm{S}_{3}$ thought that the mirror was $y$-axis so she drew the image in the quadrant IV. But when she was given the additional help, she can imagine and reflect the object, as shown on the following interview passage.

$\mathrm{P}$ : How did you get the image of the object after rotating it? Please explain to me.

$\mathrm{S}_{3}$ : The mirror was $\mathrm{x}$-axis, so the position was here (she points on quadrant II) (spatial orientation)

$\mathrm{P}$ : Are you sure that the change of the object only about position?

$\mathrm{S}_{3} \quad: \mathrm{Hm}$.... (thinking)

$\mathrm{P}$ : Try to imagine that you are stand in front of the mirror. Imagine that you are in the position of this object. So where does the image of this side lie?

$\mathrm{S}_{3}$ : (pointing the position of the object side). Oh yes, Miss. I can imagine it.
$\mathrm{P}$ : So what can you conclude from your drawing?

$\mathrm{S}_{3} \quad$ : I made a mistake, Miss.

$\mathrm{P}$ : For the second problem of reflection, how did you get the object before reflecting it?

$\mathrm{S}_{3}$ : Firstly, I assumed that the mirror was respected to y-axis. So the reflection image was in quadrant IV (spatial orientation)

For Problem I about translation, as shown in Figure 10, $\mathrm{S}_{3}$ understood the orientation of translated objects that were to the right and to the above. But the position of the translated object was incorrect because of her inaccuracy in reading the instruction. This is the passage of the interview.

$\mathrm{P}$ : Please explain to me how you draw the image which has been translated.

$\mathrm{S}_{3}$ : I shifted it 2 unit to above and 3 units to the right (spatial orientation)

$\mathrm{P}$ : Are you sure with your drawing? Check it first whether this object was translated like what you said.

$\mathrm{S}_{3} \quad$ : Oh sorry, Miss. I made mistake in reading instruction. It was read 5 units. 


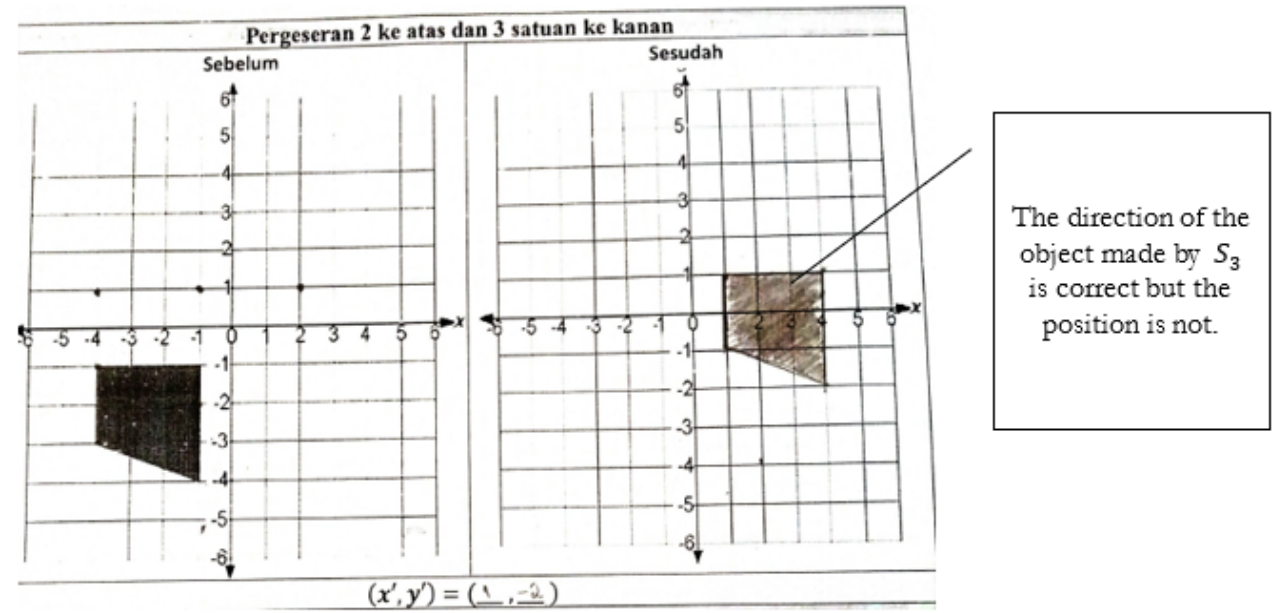

Figure 10. S3's work for Problem I about Translation ( 2 units to the up and 3 unnits to the right)

Based on the data, $\mathrm{S}_{1}$ applies drawing strategy and algebraic strategy in solving geometrical transformation. It is line with Battista (1990) who states that $\mathrm{S}_{1}$ uses two of three strategies in spatial visualization aspect. She is said to use drawing strategy because she chooses and describes the method explicitly, she draws the image of object vertices, and draws assistance lines that connect every vertex of object to the center of rotation. $\mathrm{S}_{1}$ uses non-spatial strategy to solve reflection problem to the line $\mathrm{y}=\mathrm{x}$ because she doesn't have the ability in regarding the line $y=x$.

$\mathrm{S}_{2}$ implemented a holistic strategy for the easy problems and an analytic strategy for difficult problems of geometrical transformation. This is in line with Turgut (2015) that $S_{2}$ uses two strategies in mental rotation aspect, a holistic strategy, because he has the ability to determine the image of object after it was rotated by imagining. $\mathrm{S}_{2}$ also uses an analytics strategy because it also performes a transformation as a component to help her in solving the problem.

In solving geometrical transformation problem, $\mathrm{S}_{3}$ doesn't involve object manipulation. She only can determine position and orientation the image of the object. It is line with McGee (1979) who states that in spatial orientation aspect, it does not involve the change of object. According to Hendroanto, et al. (2017), one of activity in spatial orientation aspect is determining object position from standard view.

\section{Conclusion}

From discussion above, it can be concluded that the student with spatial visualization use drawing strategy to solve geometrical transformation problem by drawing every vertex of object to center point. Besides that, she also use non-spatial strategy, which is algebraic strategy because she could not draw the line $\mathrm{y}=\mathrm{x}$.

The student with mental rotation aspect uses holistic strategy in solving geometrical transformation problem. If he get a difficulty, he will use analytic strategy. Holistic strategy is transforming object as a whole. While analytic strategy is transforming object as a component because he needs only one vertex of object to be transformed. For another vertices, he imagines the image of the object.

The student with spatial orientation doesn't involve mental imagery in transforming an object. She only can 
determine position and orientation of an object when solving geometrical transformation problem such that, she can not draw the object before or after it was transformed correctly.

\section{References}

Arcavi, A., (2003). The role of visual representations in the learning of mathematics. Educational studies in mathematics, 52(3), 215-241. doi : https://doi.org/10.1023/A:10243123210 77

Ananggih, G.W., Yuwono, I. and Sulandra, I.M., (2017). Pembelajaran Berbasis Masalah untuk Meningkatkan Pemahaman Matematika Siswa Kelas IX SMP. Jurnal Kajian Pembelajaran Matematika, 1(1), 25-35.

Bansilal, S. and Naidooo, J., (2012). Learners Engaging with Transformation Geometry. South African Journal of Education, 32(1), 26-39. doi : 10.15700/saje.v32n1a452

Battista, Michael T. (1990). Spatial Visualization and Gender Differences in High School Geometry. Journal for Research in Mathematics Education, 21(1), 47-60. doi: 10.2307/749456

Boonen, A.J., van Wesel, F., Jolles, J. and van der Schoot, M., (2014). The Role of Visual Representation Type, Spatial Ability, and Reading Comprehension in Word Problem Solving: An Item-Level Analysis in Elementary School Children. International Journal of Educational Research, 68, 15-26. doi: https://doi.org/10.1016/j.ijer.2014.08.00 1

Cai, J and Lester, F. (2010). Why is Teaching with Problem Solving Important to Student Learning? Reston, VA: National Council of Teachers of Mathematics.

Yu, K. C., Fan, S. C., \& Lin, K. Y. (2015). Enhancing Students'problem-Solving Skills Through Context-Based Learning. International Journal of Science and Mathematics Education, 13(6), 1377-
1401. doi: https://doi.org/10.1007/s10763-0149567-4.

Chapman, O. 2015. Mathematics Teachers' Knowledge for Teaching Problem Solving. Lumat, 3(1), 19-36. Diakses dari

https://www.lumat.fi/index.php/lumatold/article/view/38

Cheng, Y., \& Mix, K. S. (2014). Spatial training improves children's mathematics ability. Journal of Cognition and Development, 15, 2-11. doi : 10.1080/15248372.2012.725186

Daguplo, M.S., (2013). Non-routine Mathematical Problems: Phenomenological Analysis of Positive and Negative Learning Impact. Journal of Educational and Human Resource Development, 1, 46-58. Diakses dari https://www.ijterm.org/index.php/jehrd/ article/view/119

Garderen, Delinda V. (2006). Spatial Visualization, Visual Imagery, and Mathematical Problem Solving of Students With Varying Abilities. Journal of Learning Disabilities 39(6), 496-506. doi

https://doi.org/10.1177/0022219406039 0060201

Hardman, D. Macchi, Laura. (2004). Thinking: Psychological Perspectives on Reasoning, Judgment and Decision Making. E. John Wiley \& Sons.

Hartatiana., Darhim., Nurlaelah, E. (2018). Improving Junior High School Students' Spatial Reasoning Ability through Model Eliciting Activities with Cabri 3D. International Education Studies, 11(1), 148-154. doi: 10.5539/ies.v11n1p148

Hendoranto, A., Gallen, Frans van., Eerde, D van., Prahmana, R C I., Setyawan F., Istiandaru, A. (2017). Photography activities for developing studets' spatial orientation and spatial visualization. Journal of Physics: Conference Series. 943 012029. doi : 10.1088/17426596/943/1/012029. 
Kolovou, A., van den Heuvel-Panhuizen, M. \& Bakker, A. (2009). Non-routine problem solving tasks in primary school mathematics textbooks - a needle in a haystack. Mediterranean Journal for Research in Mathematics Education 8(2), 31-68. Diakses dari https://www.academia.edu/25369785/No $\underline{\mathrm{n}-}$

Routine Problem Solving Tasks In Pr imary_School_Mathematics_Textbooks A Needle In a Haystack

Lowrie, T., Logan, T. and Ramful, A., (2016). Spatial Reasoning Influences Students' Performance on Mathematics Tasks. Paper presented at the Annual Meeting of the Mathematics Education Research Group of Australasia (MERGA)

Lowrie, T., Logan, T., Harris, D., Hergarty, M. (2018). The Impact of an Intervention Program on Students' Spatial Reasoning: Student Engagement through Mathematics enhanced Learning Activities. Cognitive Research : Principles and Implications. 3(50), 1-10. doi : 10.1186/s41235-018-0147-y

McGee, M. (1979). Human spatial abilities: psychometric studies and environmental, genetic, hormonal,and neurological influences. Psychological Bulletin, 86, 889.

doi:

http://dx.doi.org/10.1037/00332909.86.5.889

Mukhopadhyay, Rajib. (2013). Problem Solving In Science Learning - Some Important Considerations of a Teacher. IOSR Journal of Humanities And Social Science. 8(6), 21-2.

Mulyono \& Hadiyanti, R. (2018). Analysis of mathematical problem-solving ability based on metacognition on problembased learning. Journal of Physics : Conference Series. 983 012157. doi: 10.1088/1742-6596/983/1/012157

National Research Council. (2006). Learning to Think Spatially: GIS as a Support System in The K-12 Curriculum. Washington, DC: National Academic Press.
NCTM. (2000). Principle and Standards for School Mathematics. USA: The National Council of Teachers of Mathematics, Inc.

Ontario. (2014). Paying Attention to Spatial Reasoning K-12. Toronto: Queen's printer for ontario.

Özerem, A., (2012). Misconceptions in Geometry and Suggested Solutions for Seventh Grade Students. ProcediaSocial and Behavioral Sciences, 55, 720-729. doi: 10.1016/j.sbspro.2012.09.557

Özreçberoğlu, N. \& Çağanağa, C.K. (2018). Making It Count: Strategies for Improving Problem-Solving Skills in Mathematics for Students and Teachers' Classroom Management. Eurasia Journal of Mathematics, Science and Technology Education, 14(4), 12531261. doi: https://doi.org/10.29333/ejmste/82536

Pehkonen, E., Näveri, L. and Laine, A., (2013). On Teaching Problem Solving in School Mathematics. CEPS Journal: Center for Educational Policy Studies Journal, 3(4), 9.

Ramful, A., Lowrie, T., \& Logan, T. (2016). Measurement of Spatial Ability: Construction and Validation of the Spatial Reasoning Instrument for Middle School Students. Journal of Psychoeducational Assessment, 35(7), 709-727.

doi: https://doi.org/10.1177/0734282916659 $\underline{207}$

Retnawati, H., Arlinwibowo, J., Sulistyaningsih, E. 2017. The Students' Difficulties in Completing Geometry Items of National Examination. International Journal on New Trends in Education and Their Implication, 8(4), 28-41, doi: 10.12973/iji.2017.10317a

Sayg1l, S. (2017). Examining The Problem Solving Skills and The Strategies Used by High School Students in Solving Non-routine Problems. E-International Journal of Educational Research, 8(2), 91-114 
Septia, T., Prahmana, R.C.I., Pebrianto, \& Wahyu, R. (2018). Improving Students Spatial Reasoning with Course Lab. Journal on Mathematics Education, 9(2), 327-336

Shepard, R.N. and Metzler, J., (1971). Mental Rotation of Three-dimensional Objects. Science, 171 (3972), 701-703. Diakses dari https://www.jstor.org/stable/1731476

Sholl, M.J., Acacio, J.C., Makar, R.O. and Leon, C., (2000). The Relation of Sex and Sense of Direction to Spatial Orientation in an Unfamiliar Environment. Journal of Environmental Psychology, 20(1), 17-28. doi: https://doi.org/10.1006/jevp.1999.0146

Stacey, K., (2006). What is Mathematical Thinking and Why is It Important. Progress report of the APEC project: collaborative studies on innovations for teaching and learning mathematics in different cultures (II)Lesson study focusing on mathematical thinking.

Subroto, M.T. and Si, S., (2012). Kemampuan Spasial (Spatial Ability). Prosiding Seminar Nasional Pendidikan Matematika.

Turgut, M. (2015). Individual Differences in the Mental Rotation of Turkish
Prospective Teachers. IUMPST: The Journal, 5, 1-12.

Wai, J., Lubinski, D., \& Benbow, C. P. 2009. Spatial ability for STEM domains: Aligning 50 years of cumulative psychological knowledge solidifies its importance. Journal of Educational Psychology, 101, 817-835. doi : http://dx.doi.org/10.1037/a0016127

Wright, P. (2001). School-based issues and appropriate technology. In R. C. Wicklein (Ed.), Appropriate technology for sustainable living: ITEA 50th yearbook (pp. 133-152). Reston, VA: International Technology Education Association.

Yazgan, Y. (2016). Fourth Graders and NonRoutine Problems: Are Strategies Decisive for Success?. European Journal of Education Studies. 2(4), 100120. doi : $10.5281 /$ zenodo. 154128

Yusnia, D. (2018). Analysis The Ability of Students Problem Solving on Counting Operations of Algebra Form. Journal of Mathematics Education, Science \& Technology, 3(1), 1-6. Diakses dari http://journal.umsurabaya.ac.id/index.ph $\mathrm{p} /$ matematika/article/view/1017/1323 